\title{
Zeitschrift der
}

Deutschen

Morgenlandischen

Gesellschaft

Im Auftrag der Gesellschaft herausgegeben von Ewald Wagner unter Mitwirkung von Georg Buddruss, Ernst Dammann, Tileman Grimm und Wolfgang Rollig.

Jahrlich 2 Hefte, je ca. 250 Seiten, Jahresabonnement DM 96.-

Band 127/1

Inhalt :

Nachrufe

EILERS, WILHELm: Henrik Samuel Nyberg (1889-1974)

Kolta, K. S.: Murad Kamil (1907-1975)

ENDRESS, GERHARD: Richard Walzer (1900—1975)

Aufsatze

DIEM, WeRner: Die Verba und Nomina tertiae infirmae im Semitischen

FlooR, W. M. : Bankruptcy in Qajar Iran

FRANZ STEINER VERLAG GMBH · P.O.B. 5529 - D-6200 WIESBADEN 


\section{MIDDLE}

EASTERN

STUDIES

Edited by Elie Kedourie

The Tuareg Veil

The Alexandrian Massacre of 11 June 1882 and the BRITISH OCCUPATION OF EGYPT

ISLAM AND THE SOVIET UNION

Zionist Socialism ANd THE ARAB Question, 1918-1930

Berl Katznelson and the Theory and Practice of

REVOlutionary CONSTRUCTIVISM

Jabotinsky’s Parity Plan for Palestine

Changes in the Settlement Pattern of Judea and

SAMARIA DURING JoRdANIAN RULE

Prime Minister and Assassin:

Butrus Ghali and Wardani

The Surrender of Medina

Book Reviews
Jeremy H. Keenan

M. E. Chamberlain

Geoffrey Wheeler

Yosef Gorni

Amos Perlmutter

Susan Lee Hattis

Elisha Efrat

Samir Seikaly

Elie Kedourie

Published by

FRANK CASS \& CO. LTD.

GAINSBOROUGH HOUSE, GAINSBOROUGH ROAD, LONDON E11 1RS

Annual subscription: Institutions $£ 15.00(\$ 45.00)$

Individuals $\mathfrak{£ 1 0 . 0 0 ( \$ 2 8 . 0 0 )}$ 


\section{RESEARCH METHODS IN POLITICAL SCIENCE IN ARABIC}

TAWFIC FARAH and FAISAL AL-SALEM

TABLE OF CONTENTS:

1. Scientific Knowledge

2. Formulating the research problem

3. Research Designs

4. Sampling

5. Questionnaires and Interviews

6. Statistical Methods

7. Factor Analysis and Time Series Analysis

8. Uses of the computer in Political Research

9. Writing a Research Paper Appendix Glossary of English Political Science Terms translated into Arabic.

TO ORDER:

Send a cheque for $\$ 7.00$ U.S. made payable to T. E. FARAH at P.O. Box 5486 Kuwait, State of Kuwait

Name

Address 


\section{ORIENT}

\section{German Journal for Politics and Economics of the Middle East}

\section{Vol. 18 No. 1 March 1977 \\ CONTENTS}

\section{KURZBIOGRAPHIEN/SHORT BIOGRAPHIES \\ Chedli Ayari}

Salim al-Huss

BERICHTE AUS DER FORSCHUNG/TAGUNGEN UND KONFERENZEN/

REPORTS ON RESEARCH ACTIVITIES/CONFERENCES

Development and Stability in the Mediterranean. 26.-29. Januar 1977 in Athen/26-29 January 1977 in Athens

Symposium "Agrarentwicklung im Vorderen Orıent". 21.-22. Januar 1977 in StuttgartHohenheim. Kurzbericht/Symposium "Agrarian Development in the Near and Middle East"'. 21-22 January 1977 in Stuttgart-Hohenheim. A Short Peport

Die Beschaffung Grauer Literatur in den Ländern der Arabischen Halbinsel/The Collectıon of "Report Literature" in the Countries of the Arabian Peninsula

\section{AUFSÄTZE UND HINTERGRUNDBERICHTE/STUDIES AND BACKGROUND} ARTICLES

Aref Hajjaj: Der lıbanesische Bürgerkrieg, seine palästinensischen und innerarabischen Faktoren sowie seine Auswirkungen aut den arabisch-israelischen Konflikt/The Lebanese Civil War, its Palestinian and Inner-Arabic Factors and its Effects on the Arab-Israeli Conflict.

Ursula Braun: Der europäisch-arabische Dıalog - Entwicklung und Zwischenbılanz/The European-Arab Dialogie. A First Evaluation

Thomas Koszinowski Arbeitsmarktprobleme in Saudi-Arabien. Die Bedeutung ausländischer Arbeitnehmer bei der Überwindung des Arbeıtskraftemangels/Problems of the Labour Market in Saudı Arabıa. The Significance of Foreign Workers in Overcomıng Labour Shortage

Udo Steinbach. Auf dem Wege nach Europa? Die Beztehungen zwischen der Türkei und der Europäischen Gemeinschaft durchlaufen eıne kritische Phase/On the Way Towards Europe? Relations Between Turkey and the European Community are Going Through a Critıcal Phase

Munir D. Ahmed: Die Wahlen in Pakıstan in März 1977. Eıne erste Bitanz/General Elections in Pakistan in March 1977. A First Inventory

\section{BUCHBESPRECHUNGEN/BOOK REVIEWS}

\section{BIBLIOGR.APHIE/BIBLIOGRAPHY}

Publisher: German Orient Institute. Hamburg/Federal Republic of Germany Editors: Dr Udo Steınbach, Dr. Rainer Glagow

ORIENT is published three-monthly. Price per issue DM 9,50,

annual subscription DM 36,- plus postage

\section{LESKE VERLAG + BUDRICH GMBH,} Postfach 300 406, 5090 Leverkusen 3/Germany 
A comprehensive introduction to modern Israeli Hebrew

\section{LESSONS IN MODERN HEBREW Level I}

\section{by Edna Amir Coffin}

"Reading through her text lesson after lesson, I am impressed by fresh formulations, lucid explanations, fine exercises-all done intelligently and based on solid linguistic knowledge. There is nothing available which can even compare with it.... The book will be a major contribution to the teaching of Hebrew in this country."

- Professor Arnold Band University of California, Los Angeles $\$ 9.95$

Tapes are available

The University of Michigan Press

615 East University, Ann Arbor, Michigan 48106

Please send me copy [ies] of Lessons in Modern Hebrew: Level I, at

$\$ 9.95$ per copy. Payment enclosed.

Examination copies available on request to the publisher.

Name

Address

City State Zip

Include $4 \%$ sales tax with all orders to be shipped to a Michigan address.

m. The Unizersity of Michigan Press 


\section{ENGLISH TRANSLITERATION SYSTEM}

\section{CONSONANTS}

Column Headings: $\mathrm{A}=$ Arabic, $\mathrm{P}=$ Persian, $\mathrm{OT}=$ Ottoman Turkish, $\mathrm{MT}=$ Modern Turkish

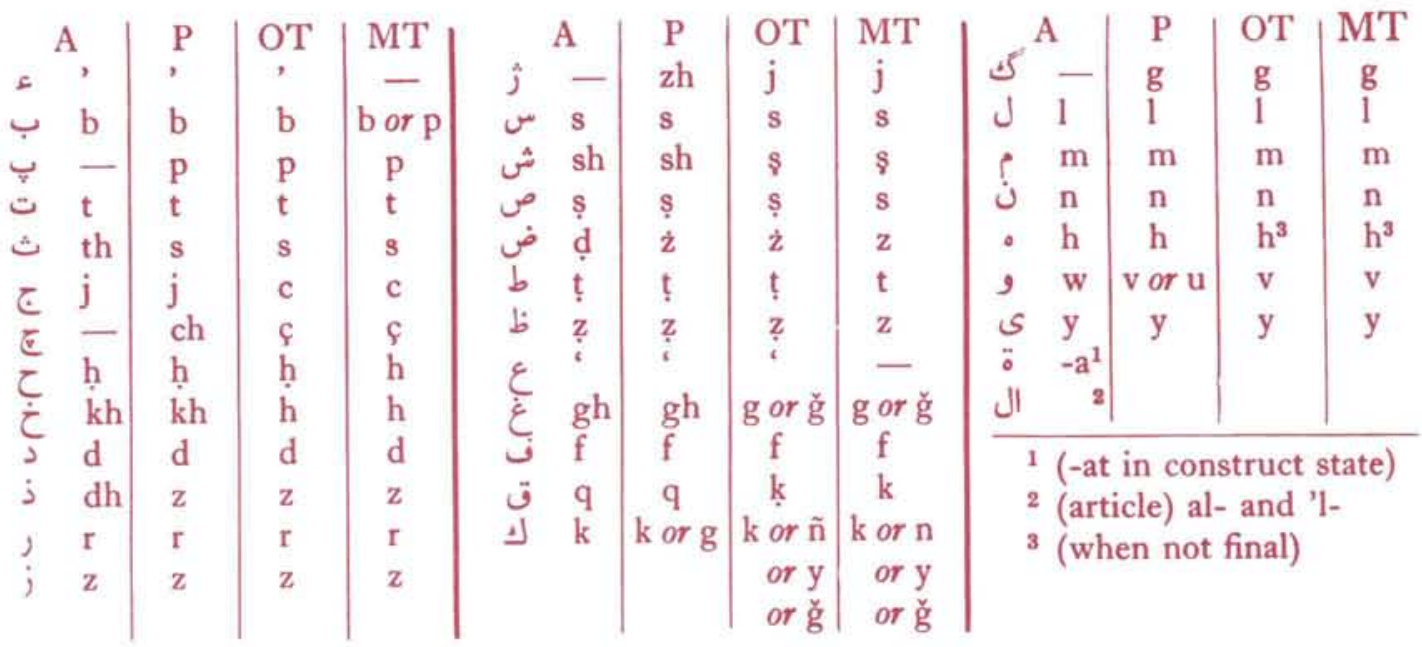

\section{VOWELS}

ARABIC AND PERSIAN

Long I or is $\bar{a}$

, $\overline{\mathrm{u}}$

ي

Doubled $\quad \approx$ iyy (final

form i)

$g^{2}$ uww (final

form $\overline{\mathrm{u}}$ ), etc.

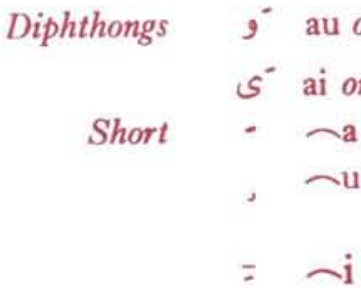

OTTOMAN TURKISH

MODERN TURKISH

$\overline{\mathrm{a}}$
$\overline{\mathrm{u}}$
$\overline{\mathrm{i}}$$\left\{\begin{array}{l}\text { words of Arabic } \\ \text { and Persian } \\ \text { origin only }\end{array}\right\} \begin{gathered}\overline{\mathrm{a}} \\ \overline{\mathrm{u}} \\ \overline{\mathrm{i}}\end{gathered}$

iy (final

form i)

uvv

ev

ey

a or $\mathrm{e}$

$\mathrm{u}$ or $\ddot{\mathrm{u}}$

o or ö

1 or $\mathrm{i}$ uvv

ev

ey

a or $\mathrm{e}$

$\mathrm{u}$ or $\ddot{\mathrm{u}}$

iy (final form ī)

o or ö

1 or $\mathrm{i}$

For Ottoman Turkish, authors may either transliterate or use the modern Turkish orthography Articles submitted in French and German may be transliterated according to the systems common in those languages. 


\section{O N T E N T S}

Hossein Askari and John Thomas Cummings The Future of Economic Integration within the Arab World

TAWFic E. FARAH and FAisal S. A. Al-SAlem Political pages $289-315$ Efficacy, Political Trust, and the Action Orientations of University Students in Kuwait

VinCENT TINTo Perceptions of Occupational Structure and Career Aspirations among the Turkish Elite

David Waines The Pre-Būyid Amirate: Two Views from the Past

Donald M. Reid Educational Career Choices of Egyptian Students, 1882-1922

Michael. J. СонеN Secret Diplomacy and Rebellion in Palestine, 1936-1939

Norman A. Stillman Recent North African Studies in Israel: A Review Article

IN MEMORIAM Cengiz Orhonlu, 1927-1976

Notes and COMMUNICATIONS

BOOK REVIEWS

\section{The Middle East Studies Association of North America, Inc.}

This association was founded in 1966 in order to promote high standards of scholarship in the field of Middle Eastern studies and to facilitate communication among scholars through meetings and publications. In addition to sponsoring the Journal, which is published for the Association by the Cambridge University Press. MESA publishes a Bulletin periodically, holds an Annual Conference, and provides other professional services for its members from time to time. Enquiries concerning membership, which includes subscription to the International Journal of Middle East Studies, should be addressed to: Headquarters and Secretariat. Middle East Studies Association, New York University, Washington Square, New York, N.Y. Iooo3, U.S.A. Fees are as follows: Fellows and associates, $\$ 30.00$; students, $\$ 12.50$; institutions, $\$ 40.00$.

\section{British Society for Middle Eastern Studies}

The Society was founded in 1973 in order to encourage and promote the study in the United Kingdom of the Middle Eastern cultural region from the end of classical antiquity and the rise of Islam. In addition to sponsoring the Journal, it publishes a Bulletin in conjunction with Mansell Information/Publishing Ltd., holds an annual conference, and hopes to provide other professional services for its members. Enquiries concerning membership should be addressed to the Secretary, Dr. D. Hopwood, St. Antony's College, Oxford. Annual subscriptions are as follows: fellows $£_{5} .00$; individual members $£_{3} .00$; corporate members $£_{25} .00$; students $£_{\mathrm{I}}$.oo. These subscriptions do not include subscription to the International Journal of Middle East Studies, but fellows and members may subscribe to the Journal at a special rate of two thirds of the present subscription price.

\section{Notes for Contributors}

Contributions and editorial correspondence should be sent to the Editor. Professor Stanford J. Shaw, The Gustave E. von Grunebaum Center for Near Eastern Studies, University of California, Los Angeles, California 90024, U.S.A. Submission of an article implies that it has not been published or is not being considered for publication elsewhere. In the interests of authors, copyright is normally assigned to the Cambridge University Press. Articles in English should conform with the Journal's transliteration system. Articles will be accepted and published in French and German, with the authors expected to follow the transliteration systems normally used in those languages. Care will be taken with manuscripts submitted, but the Editor cannot accept responsibility for any loss or damage which may take place. Short summaries should be included with every manuscript. Contributors should keep at least one copy for use in correcting proofs. Camera ready art should be provided. Contributors of articles and review articles receive 50 offprints. Extra copies may be purchased according to an agreed scale of charges. Books for review should go to the Review Editor.

\section{CAMBRIDGE UNIVERSITY PRESS \\ Bentley House, 200 Euston Road, London NWI 2DB 32 East 57th Street, New York, N.Y. I0022}

Printed in the United States of America, by the Heffernan Press, Inc., Worcester, Mass. 